KS. KAROL MOZOR

\title{
WYZNANIOWA DZIALALNOŚĆ KULTURALNO-OŚWIATOWA W POWIECIE BIELSKIM W LATACH 1918-1939
}

\author{
STRUKTURA WYZNANIOWA NA TERENIE POWIATU BIELSKIEGO.
}

Struktura wyznaniowa omawianego terenu łączy się w dużej mierze ze sprawą narodowościową. Aby ją właściwie zrozumieć trzeba sięgnąć do roku 1316, kiedy to Mieszko III podzielił Księstwo Cieszyńskie między dwóch swoich synów. Kilka lat później, w roku 1327 księstwo to wraz z Bielskiem przeszło w lenno do Czech. Po śmierci księżnej Elżbiety Lukrecji, ostatniej z rodu Piastów cieszyńskich, w roku 1653 księstwo przechodzi pod władanie austriackich Habsburgów ${ }^{1}$. Ta sytuacja doprowadziła do zaludnienia Bielska i okolicznych wiosek ludnością niemiecka. W ten sposób ludność miejscowa zetknęła się z prądami kulturalnymi i religijnymi płynącymi z zachodu.

Wystapienie Marcina Lutra odbiło się szerokim echem na całym Śląsku Cieszyńskim. Niebawem i tu znalazł on swoich zwolenników, a to głównie za sprawą księcia Wacława III Adama, który w roku 1578 uznał wyznanie augsburskie za oficjalne księstwa. Reformacja na omawianym terenie wywarła również wpływ na język. W urzędach, szczególnie Bielska stosowano przede wszystkim język niemiecki. Na początku XVII wieku sytuacja ulega zmianie na korzyść Polaków.

W połowie XIX wieku w całej Europie nastapił rozwój przemysłu. Również w Bielsku i okolicy powstały duże zakłady pracy, co spowodowało pojawienie się na tym terenie Żydów. Z kolei po odzyskaniu przez Polskę niepodległości w 1918 roku Śląsk Cieszyński został podzielony na dwie części. Zachodnia, po rzekę Olzę znalazła się w Czechach, a wschodnia w Polsce.

${ }^{1}$ Ks. A. W e gert i ks. J. S zarek, Dzieje parafii bielskiej. W: Z problemów reformacji. Warszawa 1981-1982, s. 120. 
W powiecie bielskim istniała złożona sytuacja wyznaniowa. Główne wyznania tego regionu to katolicy, protestanci oraz Żydzi. Samo miasto Bielsko było zamieszkałe przez przedstawicieli wszystkich trzech wyznań. Natomiast na wioskach mieszkali przede wszystkim katolicy i protestanci ${ }^{2} . \mathrm{Na}$ stosunki międzywyznaniowe na omawianym terenie duży wpływ miała również sprawa narodowościowa ludności. Często na tym tle dochodziło do napięć między poszczególnymi parafiami, czy nawet wewnątrz samych parafii. Napięcia te wynikały często $z$ błahych powodów. Duszpasterze pracujący wśród ludności musieli te spory rozwiązywać i doprowadzać do porozumienia $^{3}$. Stąd dla ograniczenia powstawania napięć i konfliktów w parafiach zamieszkałych przez ludność narodowości polskiej i niemieckiej odprawiano nabożeństwa w ich językach ojczystych ${ }^{4}$.

$\mathrm{Na}$ terenie powiatu bielskiego w okresie międzywojennym istniało dwanaście parafii katolickich, cztery zbory protestanckie i jedna gmina żydowska.

Tabela 1. Parafie katolickie.

\begin{tabular}{|c|c|c|c|}
\hline Lp. & Parafia i tytul & $\begin{array}{c}\text { Rok } \\
\text { założenia }\end{array}$ & Proboszczowie \\
\hline 1. & $\begin{array}{l}\text { Międzyrzecze } \\
\text { - św. Marcina biskupa }\end{array}$ & Przed 1447 & $\begin{array}{l}\text { Jan Budny }(1895-1935) \\
\text { Emil Oława } 1935\end{array}$ \\
\hline 2. & $\begin{array}{l}\text { Czechowice } \\
- \text { św. Katarzyny }\end{array}$ & 1 poł. XIV w. & Jan Harabasz (1907-1941) \\
\hline 3. & $\begin{array}{l}\text { Rudzica } \\
- \text { Św. Jana Chrzciciela }\end{array}$ & około 1320 & Ferdynand Niemiec (1924-1945) \\
\hline 4. & $\begin{array}{l}\text { Bielsko } \\
\text { - św. Mikołaja }\end{array}$ & Przed 1447 & $\begin{array}{l}\text { Józef Bulowski (1893-1932) } \\
\text { Karol Kasperlik (1932- }\end{array}$ \\
\hline 5. & $\begin{array}{l}\text { Jasienica } \\
\text { - św. Jerzego }\end{array}$ & 1335 & Ferdynand Herok (1911 \\
\hline 6. & $\begin{array}{l}\text { Zabrzeg } \\
- \text { św. Jozefa } \\
\end{array}$ & 1785 & $\begin{array}{l}\text { Karol Janoszek (1917-1933) } \\
\text { Adolf Dyczek (1933 }\end{array}$ \\
\hline 7. & $\begin{array}{l}\text { Ligota } \\
\text { - Opatrzności Bożej }\end{array}$ & 1812 & $\begin{array}{l}\text { Antoni Spaciel (1899-1936) } \\
\text { Walenty Piaskowski (1936 }\end{array}$ \\
\hline 8. & $\begin{array}{l}\text { Jaworze } \\
\text { - Opatrzności Bożej }\end{array}$ & 1847 & $\begin{array}{l}\text { Józef Hanzlik (1911-1927) } \\
\text { Jan Warzecha (1927 }\end{array}$ \\
\hline 9. & $\begin{array}{l}\text { Dziedzice } \\
\text { - N.M.P. Wspomożenia Wiernych }\end{array}$ & 1899 & $\begin{array}{l}\text { Jan Kopeć (1923-1927) } \\
\text { Karol Franek (1927 }\end{array}$ \\
\hline 10. & $\begin{array}{l}\text { Bronów } \\
\text { - N.S.P.J. }\end{array}$ & 1900 & $\begin{array}{l}\text { Jan Kunz (1908-1936) } \\
\text { Paweł Hojka (1936 }\end{array}$ \\
\hline íi. & $\begin{array}{l}\text { Kamienica } \\
- \text { św. Małgorzaty }\end{array}$ & 1903 & Robert Kiisz (i913 \\
\hline 12. & $\begin{array}{l}\text { Mazańcowice } \\
\text { - Marii Magdaleny }\end{array}$ & 1911 & Stanisław Nowak (1911 \\
\hline
\end{tabular}

${ }^{2}$ Schematyzm Diecezji Katowickiej. Katowice 1927, s. 22-27; 1938, s. 34-40.

${ }^{3}$ Relacja ustna: Helena Płachciok, Jaworze, 1985.

${ }^{4}$ J. K u ś, Szkice z dziejów kościelnych Bielska Białej. Kraków 1985, s. 201. 
W powyższej tabeli zostały przedstawione wszystkie katolickie parafie, które istniały na terenie powiatu bielskiego w okresie międzywojennym. Zostały również podane lata ich erygowania, oraz imiona i nazwiska proboszczów, którzy w interesującym nas okresie byli odpowiedzialni za powierzone sobie dusze. Trzeba także dodać, że w tych parafiach, w których liczba wiernych była większa, dla dobra wiernych pracowali również wikarzy. Jak można zauważyć z powyższej, tabeli w okresie międzywojennym na interesującym nas terenie nie erygowano żadnej nowej parafii. Na poszczególne parafie składało się nieraz po kilka wiosek czy przysiółków, dlatego kontakt duszpasterza $\mathrm{z}$ wiernymi był utrudniony.

Tabela 2. Parafie ewangelickie (zbory).

\begin{tabular}{|c|l|c|l|}
\hline Lp. & \multicolumn{1}{|c|}{ Parafia } & Rok & \multicolumn{1}{|c|}{ Proboszcz } \\
\hline 1. & Bielsko & 1566 & $\begin{array}{l}\text { Artur Schmidt (1896-1924) } \\
\text { Paweł Kanet (1924 }\end{array}$ \\
\hline 2. & Jaworze & 1781 & $\begin{array}{l}\text { Jan Lasota (1910-1932) } \\
\text { Artur Grim (1932 }\end{array}$ \\
\hline 3. & Stare Bielsko & 1818 & Hugon Bartling (1910-1945) \\
\hline 4. & Międzyrzecze & 1866 & $\begin{array}{l}\text { Paweł Pustówka (1889-1927) } \\
\text { Jan Gajdzica (1927 }\end{array}$ \\
\hline
\end{tabular}

$\mathrm{Na}$ tym samym terenie mieli również swoje zbory ewangelicy. W powyższej tabeli zostały one przedstawione. Podano także rok ich założenia, oraz pastorów, którzy stali na ich czele. Podobnie jak miało to miejsce w parafiach katolickich, tak również $w$ tych zborach gdzie liczba wiernych była większa proboszcz miał do pomocy wikarych. Poszczególne zbory obejmowały po kilka miejscowości, dlatego dotarcie nieraz do wszystkich parafian było utrudnione.

Na szczególną uwagę zasługuje istnienie w powiecie bielskim gminy żydowskiej. Trudno podać dokładną datę jej powstania. Możemy przypuszczać, że wiąże się to $\mathrm{z}$ rozwojem na tym terenie przemysłu włókienniczego, maszynowego i handlu od początku XIX wieku. Z kolei w latach międzywojennych głównym skupiskiem Żydów na omawianym terenie było Bielsko. Poza jego granicami mieszkały na poszczególnych wioskach tylko nieliczne rodziny. Gmina ta posiadała także w Bielsku swoja synagogę. Czas jej budowy nie jest znany. Uległa ona spaleniu w czasie II. wojny światowej i nigdy nie została odbudowana. Przez cały okres międzywojenny na jej czele stał rabin dr Steiners.

Po odzyskaniu niepodległości Bielsko zajmowało pierwsze miejsce pod względem uprzemysłowienia na polskim Śląsku Cieszyńskim. Oprócz Bielska zakłady przemysłowe znajdowały się w następujących miejscowościach: Jaworzu, Jasienicy, Wapienicy, Czechowicach, Dziedzicach, Kamienicy. Do dziś znajduje w nich zatrudnienie miejscowa ludność.

${ }^{5} \mathrm{~K} . \mathrm{M}$ at u si a , Szkolnictwo polskie na terenie miasta i powiatu bielskiego $w$ latach międzywojennych. Katowice 1969, s. 9. 
Ludność powiatu bielskiego pod względem zatrudnienia można podzielić na kilka grup. Pierwszą z nich stanowią robotnicy zatrudnieni w fabrykach. Druga grupa to tzw. chłopo-robotnicy, którzy posiadają zbyt małe gospodarstwa aby się z nich utrzymać, dlatego podejmują pracę w miejscowych zakładach. Przedstawicieli tej grupy można znaleźć w każdej miejscowości. Kolejna grupa społeczna to rolnicy, utrzymujący się wyłącznie z pracy na swych gospodarstwach. Czwarta z kolei grupa to mieszczanie skupiajacy w swych rękach cały handel. Największa ich liczba zamieszkuje samo Bielsko. Ostatnia grupa to inteligencja, do której możemy zaliczyć nauczycieli, duchowieństwo poszczególnych wyznan oraz wyższych urzędników państwowych.

\section{ROZWÓJ SZKOLNICTWA}

Rozwój społeczeństwa zależy w dużej mierze od świadomości obywateli oraz od wartości na których ono się opera. Miejscem ich kształtowania jest rodzina, szkoła, parafia. Sytuacja szkolnictwa na omawianym terenie była bardzo skomplikowana, co wynikało zarówno z różnic wyznaniowych jak i narodowościowych. W codziennym użyciu był język polski jak i niemiecki, a Bielsko i jego okolice były przesiąnnięte duchem niemieckim, dlatego władze polskie natrafiały na opór przy wprowadzaniu do szkół języka ojczystego. Opór ten pochodził nie tylko ze strony Niemców czy Żydów, ale także ze strony części zdezorientowanego społeczeństwa polskiego, które domagało się zapisu swoich dzieci do szkół niemieckich. W związku z tym Komisja szkolna Księstwa Cieszyńskiego i Rada Narodowa wydały w 1919 roku rozporządzenie, w myśl którego wszystkie dzieci wstępujące lub uczęszczające do szkól na Śląsku musiały stanąć przed Miejscowymi Komisjami Opisowymi. Komisja taka składała się z przedstawicieli społeczeństwa polskiego i niemieckiego, jak również reprezentantów szkół obu narodowości. Do zadań tych komisji należało przeegzaminowanie uczniów ze znajomości języka polskiego i niemieckiego, oraz przebadanie pochodzenia rodziców i wpisanie do szkoły o odpowiednim języku nauczania. Od tych decyzji można było się odwołać do Powiatowej Komisji Opisowej, której Przewodniczącym był inspektor ${ }^{6}$.

Pierwsza polska szkoła w Bielsku powstała dopiero w 1919 roku. Było to spowodowane między innymi tym, że było ono zamieszkałe przede wszystkim przez ludność narodowości niemieckiej. Na mieszkającą tam lụdność polska, na jej świadomość narodową oddziaływały organizacje polskie z oddalonego o około 30 kilometrów Cieszyna. Oddziaływanie polskich organizacji z pobliskiego miasta Białej na miejscową ludność było minimalne ze względu na nienajlepsze stosunki panujące między władzami obu miast ${ }^{7}$.

\footnotetext{
${ }^{6}$ Tamże, s. 11 .

${ }^{7}$ Relacja ustna: Karol Jaworski, Jaworze 1986.
} 
W samym Bielsku jak i jego okolicy dobrze działały niemieckie szkoły powszechne i wydziałowe. Utrzymywane one były przez Rząd Krajowy w Opawie. Oprócz szkół państwowych, niemieckie towarzystwo Deutscher Schulverein zakładało i utrzymywało szkoły prywatne. Dotyczyło to przede wszystkim tych miejscowości, gdzie liczba dzieci niemieckich nie była zbyt wysoka, co nie dawało podstaw do zakładania szkół z niemieckim językiem nauczania. Do miejscowości tych należały między innymi Czechowice, Dziedzice, Komorowice Śląskie, Mazańcowice, Jaworze Średnie. Lekcje religii pobierały dzieci w szkołach w swych jezykach ojczystych. Katechetami byli przede wszystkim księża.

Skoncentrujemy się teraz na poszczególnych miejscowościach i sytuacji szkół w nich istniejacych. W 1906 roku w Dziedzicach nastąpiło otwarcie jednoklasowej szkoły niemieckiej w budynku Kolei Północnej. Ze względu na małą ilość dzieci niemieckich, agitowano do niej dzieci polskie opłacając im przejazd koleją. Do szkoły tej uczęszczały również dzieci z rodzin miejscowych Żydów. Wraz z rozpoczęciem działalności Komisji Opisowej liczba uczniów niemieckich zaczęła szybko się zmniejszać. W związku z tym ostatnim rokiem jej działalności był rok szkolny 1933/34. W tym roku szkoła została zamknięta, a budynek odkupiła gmina Dziedzice umieszczając w nim szkołe powszechną nr 4. - W związku ze wspólnymi interesami ludności Dziedzic i Czechowic zaczęto zabiegać wspólnie o założenie polskiej szkoły wydziałowej. Jej zadaniem miało być przede wszystkim przeciwstawienie się germanizacji niemieckiej. W związku z tym problemem ludność tych miejscowości zwróciła się o pomoc do Towarzystwa Szkoły Ludowej w Krakowie. Towarzystwo krakowskie przyszło z pomocą i w 1910 roku szkoła wydziałowa została założona. Nowy budynek tej szkoły został oddany już w 1911 roku, który był wybudowany na gruncie ofiarowanym przez jednego z mieszkańców ${ }^{8}$.

Kolejną miejscowością w której problem szkolnictwa był mocno skomplikowany to Jaworze. Składało się ono $\mathrm{z}$ wielu dzielnic. W Jaworzu Centrum istniała siedmioklasowa szkoła $z$ dwoma językami nauczania. W Jaworzu Nałężu szkoła była tylko jednoklasowa. Natomiast Jaworze Średnie, leżące bliżej Wapienicy i Bielska nie posiadało szkoły. W związku z tym Niemcy w 1910 roku założyli w tej dzielnicy własną szkołę jednoklasową. Do 1912 roku wzniesiono nowy budynek i szkolę powiększono do dwuklasowej. Polacy mieszkający w tej dzielnicy Jaworza nie pozostawali obojętni na poczynania Niemców. W tym samym roku tj. 1910 otworzono prywatna jednoklasową szkołę polską $\mathrm{w}$ budynku zakupionym od Jerzego Könika, w pobliżu szkoły niemieckiej. W następnych latach została ona powiększona do dwóch oddziałów. Po rozpoczęciu działalności Komisji Opisowej stwierdzono, że większość dzieci dobrze włada językiem polskim, przez co zapisano je do szkoły polskiej. W związku z tym w 1919 roku szkoła niemiecka

\footnotetext{
${ }^{8}$ Klemens M at u s i a k, Szkolnictwo..., s. 13, 18.
} 
w Jaworzu Średnim przestała istnieć, a szkoła polska pozostała jedyną na tym terenie ${ }^{9}$.

Mazańcowice, wioska leżąca w niedużej odległości od Bielska borykała się z następującym problemem. Istniały w niej dwie polskie szkoły wyznaniowe: katolicka i prywatna ewangelicka. Szkoła ewangelicka od 1910 roku została przemieniona na niemiecka, przez co i językiem wykładowym został język niemiecki. Szkoła ta była czteroklasowa do 1918 roku, kiedy to z braku odpowiedniej ilości uczniów zredukowano ją do jednoklasowej ${ }^{10}$.

Komorowice Śląskie, wioska leżąca nad lewym brzegiem rzeki Białej w przeciwieństwie do Komorowic Krakowskich nie posiadała polskiej szkoły, mimo, że większość mieszkańców była Polakami. Miejscowość ta posiadała prywatną szkołę ewangelicką założoną w 1869 roku. Dzieci rodzin polskich katolików uczęszczały do polskich szkół w Komorowicach Krakowskich lub do Mazańcowic. W 1918 roku rozpoczęto starania o założenie polskiej szkoły w tej miejscowości. Starania te zostały uwieńczone sukcesem. Początkowo była to szkoła jednoklasowa do której uczęszczały dzieci polskie zarówno katolickie jak i ewangelickie. W 1936 roku w tej miejscowości wzniesiono nowy gmach czteroklasowej szkoły wraz z salami dla przedszkola.

W lipcu 1919 roku przybył do Bielska inspektor szkolny Klemens Matusiak, jako przedstawiciel Komisji Szkolnej Księstwa Cieszyńskiego. Miasto, w którego zarządzie zasiadali przede wszystkim Niemcy oddało do jego dyspozycji sale znajdujące się w budynku, w którym mieściły się niemieckie: gimnazjum, szkoła realna i pięcioklasowa katolicka szkoła powszechna $\mathrm{nr} 4$. Inspektor był świadomy tego, że ilość dzieci uczęszczających do polskich szkół będzie w dużej mierze zależała od akcji przeprowadzonej przez czynniki polskie. W związku z tym od razu mianował już wcześniej upatrzonych nauczycieli. Dekrety te otrzymali: Franciszek Obrzut - kierownik szkoły, Augustyn Kubica, Władysław Suchoń, Teodor Sadlik, Zofia Faryniakówna. Nauczyciele ci prowadzili bardzo szeroką działalność społeczną. Zaczęto tworzyć komitety rodzicielskie, których celem była agitacja wśród rodzin polskich, aby dzieci zostały posłane do nowo otwartej szkoły. Ku zaskoczeniu Polaków i przerażeniu Niemców do polskiej szkoły w roku szkolnym $1919 / 1920$ zgłosiło się 260 dzieci. Szkoła ta została uznana za międzywyznaniową w przeciwieństwie do szkół niemieckich, które były wyznaniowymi.

Sytuacja szkolnictwa niemieckiego na terenie Bielska w roku szkolnym $19 \hat{1} \overline{8} / 1919$ przedstawiała się następująco. $\bar{W}$ mieście było $\bar{T}$ szḱkół podstawowych o 47 klasach z niemieckim językiem wykładowym, nie wliczając oddziałów równoległych. Były to następujące szkoły:

${ }^{9}$ Karol J aw orski, Zarys historii szkól w Jaworzu, s. 5. (Maszynopis w posiadaniu autora).

${ }_{10}$ Franciszek Lorenz i Leszek Szendzielarz, Duma Mazańcowicz. Cieszyn 1999 , s. 37. 
- katolicka męska nr 1 (pięcioklasowa z trzyklasową szkołą wydziałowa);

- ewangelicka męska nr 2 (pięcioklasowa z trzyklasową szkołą wydziałowa);

- ewangelicka żeńska nr 1 (pięcioklasowa z trzyklasową szkolą wydziałowa);

- $\quad$ katolicka męska nr 4 (pięcioklasowa);

- żydowska męska nr 3 (pięcioklasowa);

- żydowska żeńska nr 2 (pięcioklasowa);

- katolicka prywatna żeńska $\mathrm{z}$ trzyklasową szkołą wydziałową sióstr de Notre Dame.

Wraz z otwarciem polskiej szkoły w 1919 roku zlikwidowano szkołę niemiecką nr 4.

Polska szkoła w Bielsku rozwijała się bardzo szybko. W drugimi roku jej działalności otworzono pierwszą klasę szkoły wydziałowej. W następnych latach otwierano następne klasy, a także ze względu na dużą liczbę uczniów zaczęto tworzyć klasy równoległe. W roku szkolnym 1923/24 doszło do podziału szkoły na męską i żeńska, podstawową i wydziałową.

Klemens Matusiak, inspektor szkół polskich cieszył się również dużym zaufaniem ze strony Niemców. Od roku 1922 zaczął sprawować swoją władzę również nad ich szkołami. Funkcję tę pełnił na wyłączną prośbe przedstawicieli ludności niemieckiej. Jednak na skutek wzrostu uczniów w polskich szkołach następował spadek liczby uczniów w szkołach niemieckich. Inspektor szkolny w związku $\mathrm{z}$ zaistniałą sytuacją był zmuszony $\mathrm{w}$ wyżej wymienionych szkołach niemieckich zlikwidować najpierw klasy równoległe, a następnie połączyć szkolę realną z gimnazjum.

Polskie władze Oświecenia Publicznego w 1922 roku przeniosły trzy klasy nowo otworzonego gimnazjum ze Skoczowa do Bielska. Równocześnie rozpoczęto budowę nowego gmachu dla tej szkoły, do której przeniesiono ją w 1927 roku. W związku z dalszym spadkiem liczby uczniów w szkołach niemieckich w 1932 roku doszło do połączenia dwóch szkół niemieckich nr 1 i nr 2, tzw. katolickiej i ewangelickiej. Budynek po szkole nr 1 zajęła nowo utworzona polska szkoła męska wydziałowa.

Bielsko było zamieszkałe przez stosunkowo dużą liczbę Żydów. Zaliczali się oni, z małymi wyjątkami, do radykalnych Niemców. Gmina żydowska posiadała w Bielsku dwie szkoły: podstawową męską nr 3 i żeńską $\mathrm{nr} 2$. Językiem nauczania $w$ tych szkołach był język niemiecki, lecz i w nich $\mathrm{z}$ biegiem lat udało się wprowadzić do nauczania język polski ${ }^{11}$.

Redukcja szkół niemieckich przez władze szkolne nie podobała się Niemcom czego zresztą nie ukrywali. Chcąc ratować swoje szkolnictwo poseł niemiecki z Bielska Robert Piesch udał się do inspektora powiatowego z propozycją likwidacji dwóch szkół żydowskich, zamiast redukować niemiecką szkołę ewangelicką i żydowską. O wszystkich poczynaniach Niemców dowiedziała się gmina żydowska. Pod przewodnictwem rabina dr. Ste-

\footnotetext{
${ }^{11}$ Klemens Matus i a k, Szkolnictwo..., s. 33.
} 
inera udała się delegacja tej gminy do inspektora z protestem. Gmina żydowska chcąc ratować swoje szkoły miała zamiar przekształcić je w prywatne, o niemieckim języku wykładowym. Było to niemożliwe w związku z dużą ilością wolnych miejsc w szkołach niemieckich. Dlatego inspektor wyszedł z propozycją otwarcia prywatnej szkoły żydowskiej, w której nauka będzie się odbywała $w$ języku polskim. Żydzi nie widząc innego wyjścia, bardziej rozsądnego, zgodzili się na propozycję inspektora. I tak od roku szkolnego $1927 / 28$ w tych szkołach językiem wykładowym był język polski. W związku z pozytywnym załatwieniem sprawy inspektor pomógł wyasygnować od Wojewódzkiego Wydziału Oświecenia Publicznego 20000 złotych na wydatki szkolne. To wydarzenie wpłynęło na pogorszenie stosunków między Żydami a Niemcami w Bielsku ${ }^{12}$.

Redukcja szkół niemieckich oraz klas równoległych miała także wpływ na redukcje wśród nauczycieli niemieckich. Spotkało to przede wszystkim nauczycieli najstarszych i najmłodszych. Wśród nich były między innymi córka pastora dr Artura Schmidta oraz córka byłego inspektora szkół niemieckich Junga. Redukcja nauczycieli niemieckich nie przysporzyła inspektorowi wrogów, wprost przeciwnie, zyskał sobie miano człowieka sprawiedliwego. Dalsza zmniejszająca się ilość uczniów w szkołach niemieckich doprowadziła do zmiany szkół z pięcioklasowych na czteroklasowe. Z kolei na podstawie rozporządzenia Ministra Wyznań Religijnych i Oświecenia Publicznego zlikwidowano 30.06 .1932 roku publiczną szkołe wydziałowa z niemieckim językiem nauczania. Doszło także do połączenia dwóch szkół niemieckich, mianowicie: męskiej katolickiej i męskiej ewangelickiej. Mimo niezadowolenia ludności niemieckiej z zaistniałej sytuacji, nie mając innego wyjścia musiano się z nią pogodzić.

Na początku lat dwudziestych brakowało dzieci w gminach Mikuszowice i Bystra do otwarcia polskiej szkoły. Jeden z powodów to ten, że dzieci polskich robotników uczęszczały do szkoły niemieckiej z obawy przed utrata przez rodziców pracy u niemieckiego kapitalisty, od którego byli oni uzależnieni. Zdarzało się również, iż fabrykanci nakazywali polskim rodzinom posyłać swoje dzieci do polskich szkół w Bielsku opłacając im równocześnie przejazd. Tak na przykład w Mikuszowicach inż. Zipser, fabrykant, a zarazem wójt gminy, zażądał od swych robotników Polaków, aby swe dzieci posyłali do szkół polskich w Bielsku. On natomiast opłacał im za przejazdy tramwajem przez cały rok szkolny. - W celu otwarcia polskiej szkoły w tych gminach połączono je w jedną. Po tym połączeniu do nowo otwartej polskiej szkoły zâpisano 47 dzieci. W związku z tym w budynku szkolnym w Bystroj umieszczono polską szkołę, a w budynku szkolnym w Mikuszowicach szkołę niemiecką. Sytuacja ta wywołała dużą radość wśród ludności polskiej obu miejscowości. Liczba dzieci w polskiej szkole zaczęła szybko wzrastać. Wynikało to stąd, że te które dotychczas dojeżdżały do polskich szkół w Bielsku zostały przepisane do szkoły miejscowej.

${ }^{12}$ N.N. (Relacja ustna, Bielsko, 1987 r. - nazwisko znane autorowi). 
Wapienica, miejscowość leżąca na obrzeżach Bielska była w dużej mierze zamieszkała przez Niemców. Dogodne warunki do założenia w niej polskiej szkoły pojawiły się dopiero w 1920 roku. Kierownikiem nowo otwartej szkoły mianowano Franciszka Kuboka. Ludność niemiecka starała się różnymi sposobami przeszkodzić w jej otwarciu. Po dwóch latach władze zdecydowały się wybudować dla niej nowy budynek. Oddano go do użytku w 1922 roku. Jego poświęcenia dokonał proboszcz parafii św. Mikołaja w Bielsku ks. Karol Kasperlik. Po odjeździe ks. Kasperlika zabrał głos pastor ewangelicki z Jaworza ks. Jan Lasota. W swym przemówieniu zachęcał protestantów, aby posyłali swe dzieci do nowo otwartej szkoły. Wraz z rozwojem szkoły polskiej, szkoła niemiecka została zredukowana z pięcioklasowej do dwuklasowej.

Ludność Kamienicy była w większości protestancka. W miejscowości tej znajdowały się dwie szkoły niemieckie: katolicka i ewangelicka. W roku 1920 podjęto próbę założenia w niej szkoły polskiej. Zostało zapisane do niej 27 dzieci. Nie dawało to podstaw aby gmina przeznaczyła na ten cel jakieś pomieszczenie. W związku $\mathrm{z}$ tym zwrócono się $\mathrm{z}$ prośbą do miejscowego proboszcza, aby w katolickiej szkole niemieckiej przeznaczył na ten cel jedną salę. Proboszcz, jak i sami mieszkańcy odnieśli się do propozycji pozytywnie bez większych sprzeciwów. Według rozporządzenia Komisji Szkolnej w Cieszynie do otwarcia samodzielnej szkoły było wymagane minimum 31 uczniów. Kierownikiem nowo otwartej szkoły został mianowany Alojzy Kołodziej. Przekonywał on rodziców do przepisywania swoich dzieci ze szkoły niemieckiej do nowo otwartej szkoły polskiej. Doprowadziło to z jednej strony do wzrostu liczby dzieci w polskiej szkole do 37, z drugiej strony do protestu kierownika szkoły niemieckiej skierowanego na ręce inspektora. Drażliwy problem został załatwiony pomyślnie. Kierownik polskiej szkoły Kołodziej przeprosił kierownika szkoły niemieckiej Zeitzingera za stworzoną sytuację. Inspektor natomiast zakazał przyjmowania uczniów do polskiej szkoły w czasie trwania roku szkolnego. $Z$ biegiem lat szkoła ta rozrosła się do dwuklasowej, natomiast szkoła niemiecka została zredukowana do trzyklasowej.

Jednoklasowa polska szkoła w Starym Bielsku została założona w 1920 roku do której zapisano 38 dzieci. Założenie jej nie natrafiało na żadne trudności ze strony miejscowej władzy. Oprócz tego istniała tam od 1902 roku niemiecka sześcioklasowa szkoła powszechna międzywyznaniowa. Liczba uczniów w polskiej szkole pozostawała na tym samym poziomie, w związku $\mathrm{z}$ tym, że większość mieszkańców tej miejscowości była narodowości niemieckiej.

Kolejną miejscowością w której założono polską szkołę to Aleksandrowice. Jej otwarcie nie nastręczało większych trudności ponieważ opisy szkolne wykazały odpowiednią ilość dzieci polskich. W następnych latach szkoła ta wzrosła do dwuklasowej ${ }^{13}$.

${ }^{13}$ Klemens Mat u s i a k, Szkolnictwo..., s. 35. 
Bardziej skomplikowana sytuacja szkolnictwa miała miejsce w Międzyrzeczu Górnym. W miejscowości tej istniały dwie szkoły: polska dwuklasowa i niemiecka pięcioklasowa. W polskiej przeważali katolicy, zaś w niemieckiej ewangelicy. Czynnikiem hamującym przejście dzieci polskich, albo ewangelickich do szkoły polskiej i odwrotnie, był fakt, że obie istniały przy kościołach. Przydziały dzieci ewangelickich do polskiej szkoły, które przeprowadzała Komisja Opisowa spowodowały protesty rodziców. Doprowadzito to również do strajku samych dzieci. Rodzice w dalszym ciągu posyłali je do szkoły niemieckiej, lecz tam je nie wpuszczano, ponieważ nie były do niej zapisane. W ten sposób 37 dzieci praktycznie nie uczęszczało do żadnej szkoły. W kwietniu następnego roku sprawa stała się na tyle poważna, że posłowie wnieśli interpelację do ministra oświaty. Od inspektora powiatowego zażądano wyjaśnień w tej sprawie i zdania relacji co się robi aby strajk był zakończony. Inspektor obawiając się aby sprawa nie obróciła się na niekorzyść szkolnictwa polskiego zaproponował inspektorowi niemieckiemu Jungowi, rodzicom strajkujących dzieci oraz miejscowej władzy następujące rozwiązanie. Do końca roku szkolnego wszystkie dzieci pójdą do szkoły polskiej, natomiast wraz z rozpoczęciem nowego roku szkolnego, starsze z nich przejdą $z$ powrotem do szkoły niemieckiej. Władze gminne bez wahania poparły propozycję inspektora, natomiast rodzice po krótkiej dyskusji, również zgodzili się na proponowane rozwiązanie. Akta pozytywnie załatwionej sprawy zostały przesłane do ministerstwa. Po wakacjach zgodnie $\mathrm{z}$ obietnica 9 najstarszych uczniów przekazano z powrotem do szkoły niemieckiej ${ }^{14}$.

Podsumowujacc problem szkolnictwa w powiecie bielskim trzeba stwierdzić, że po odzyskaniu przez Polskę niepodległości następowało szybkie jego odrodzenie. Przed wybuchem drugiej wojny światowej do szkól uczęszczało 12987 uczniów, z tego 10666 do szkól polskich, co stanowi 82\% całej młodzieży; natomiast do szkół niemieckich uczęszczało 2321 uczniów, co stanowi $18 \%$. Czynnikiem, który niewątpliwie przyczynił się do rozwoju polskiego szkolnictwa było rozporządzenie Rady Narodowej Księstwa Cieszyńskiego, odnośnie opisów szkolnych, jak również polityka miejscowych władz szkolnych. Duże osobiste zasługi na tym polu mieli inspektor powiatowy Klemens Matusiak, wojewoda śląski Michał Grażyński oraz naczelnik Wydziału Oświecenia Publicznego, Ludwik Ręgorowicz ${ }^{15}$.

Omawiając sytuację szkolnictwa na terenie powiatu bielskiego trzeba również wspomnieć o nauczycielach i ich roli jaką odgrywali w kształtowaniu młodego pokolenia. Nauczyciele poszczególnych narodowości chętnie współpracowali ze soba, co wpływało pozytywnie na postawy ich wychowanków. Postawy wzajemnej wrogości należały do rzadkości. Przykładem dobrej atmosfery panującej wśród nauczycieli polskich i niemieckich był artykuł w „Zjednoczeniu” z roku 1933. Autor podkreślił, iż podczas powiato-

${ }_{15}^{14}$ Miedzyrzecze (B.m.w.), s. 29. (Broszura w posiadaniu autora).

${ }^{15}$ K. M a tu si ak, Szkolnictwo..., s. 45. 
wej konferencji nauczycielskiej nastrój wśród zebranych był miły ${ }^{16}$. Dużą zasługę na tym polu, o czym była już mowa wcześniej, miał inspektor powiatowy Klemens Matusiak, który zawsze starał się być człowiekiem sprawiedliwym.

\section{DZIALALNOŚĆ WYDAWNICZA.}

Rozwój nauki i szkolnictwa przyczynia się do rozwoju świadomości obywateli, a co zatem idzie do większego zapotrzebowania na dobrą książkę i prasę. Mimo nieobecności polski na mapie świata od końca XVIII wieku, język polski istniał i nadal następował jego rozwój. Największa swoboda posługiwania się językiem polskim istniała w zaborze austro-węgierskim. Tutaj istniało najwięcej polskich szkół, wychodziły polskie książki i czasopisma. Od 1848 roku zaczęło ukazywać się w Cieszynie czasopismo „Gwiazdka Cieszyńska", które poruszało na swych łamach problemy nurtujące ludność Śląska Cieszyńskiego. Czasopismo to mimo różnych perypetii ukazywało się bez przerwy do roku 1939. Odegrało ono dużą rolę w kształtowaniu świadomości narodowej i religijnej u miejscowej ludności polskiej, szczególnie po odzyskaniu niepodległości.

Do roku 1918 na terenie powiatu bielskiego ukazywały się następujące czasopisma w języku polskim:

- „Cepy”, czasopismo satyryczne, ludowe, miesięcznik, miejscem wydania było Bielsko i Biała, 1:1906 - 5:1911;

- „Gazeta Bielska”, tygodnik, miejscem wydania było Bielsko, 1:1912 3:1914;

- „Gazeta Żandarmerii”, ukazywała się trzy razy w miesiącu, miejscem wydania było Bielsko; 1:1902;

- "Gospodarz", dodatek do Wieńca - Pszczółki, pismo dla rolników, miejscem wydania było Bielsko, 1:1900 - 16:1916;

- „Kolejarz Chrześcijański”, organ niezależnych kolejarzy w Austrii, miejscem wydania było Bielsko, 1:1913 - 2:1914;

- "Listy Ludowe", miesięcznik, miejscem wydania było Bielsko, 1:1902 2:1903;

- „Niewiasta”, dwutygodnik, dodatek do Wieńca - Pszczółki, miejscem wydania było Bielsko i Cieszyn, 1:1896 - 10:1910;

- „Robotnik Chrześcijański”, miejscem wydania było Bielsko, 1:1907;

- „Robotnik Tkacki”, dwutygodnik, miejscem wydania było Bielsko, 1:1907/1908 ${ }^{17}$.

Ludność zamieszkująca omawiany teren na skutek rozwoju szkolnictwa i przemysłu coraz bardziej kształtowała w sobie świadomość roli jaką odgrywa w życiu społecznym. Różnorodność wyznań i narodowości była do-

${ }^{16}$ Zjednoczenie. Tygodnik Narodowo-Chrześcijańskiego Zjednoczenia Pracy na Polskim Śląsku Cieszyńskim, (Bielsko), z 16.04.1933, s. 275.

${ }^{17}$ Archiwum Prywatne ks. Józefa Krętosza w Katowicach, Notatki luźne. 
datkowym czynnikiem mobilizującym. To powodowało, że każda $\mathrm{z}$ tych grup starała się być aktywną na różnych płaszczyznach codziennego życia.

Na początku XX wieku została otwarta w Bielsku drukarnia, której założycielami byli Niemcy. W okresie międzywojennym jej właścicielami były władze miejskie. Drukowano w niej książki zarówno w języku polskim jak i niemieckim. W czasie działań wojennych cała dokumentacja drukarni uległa zniszczeniu ${ }^{18}$.

Oprócz książek drukowanych w miejscowej drukarni docierały na teren powiatu bielskiego pozycje drukowane $w$ innych rejonach polski oraz poza jej granicami. Jeżeli chodzi o książki w języku polskim były one najczęściej przywożone z Krakowa, Warszawy i Lwowa, a gdy chodzi o książki w języku niemieckim to $\mathrm{z}$ terenu Niemiec.

Większą rolę od książek spełniały czasopisma. W okresie międzywojennym na omawianym terenie ukazywało się 39 tytułów: Czasopisma te obejmowały swą treścią wszystkie zagadnienia interesujące mieszkających tam ludzi. Są one wydawane przez różne organizacje polityczne i społeczne; maja charakter pouczający $\mathrm{i}$ uświadamiający. Czas ich ukazywania się był różny. Niektóre z nich jak np. "Gazeta Mieszkaniowa” ukazywały się tylko kilka miesięcy, a inne np. „Młody Narodowiec” wychodziły aż do wybuchu II wojny światowej. Również ich nakład był różny i wynosił od kilkuset do kilku tysięcy egzemplarzy. Było to uzależnione od kręgu osób do którego czasopismo zostawało skierowane. Czynnikiem wpływającym na rozwój prasy była niska cena czasopism, co umożliwiało ich nabywanie nawet ludziom niezamożnym.

Oto niektóre ważniejsze tytuły czasopism ukazujące się na tym terenie w omawianym okresie:

- „Dziennik Urzędowy”, miesięcznik, Dziennik Urzędowy Starostwa w Bielsku i Rady Szkolnej Okręgowej dla Okręgu Bielskiego Zamiejskiego, miejscem wydania było Bielsko, 1:1899 - 22:1920;

- "Głos Robotniczy", miesięcznik, miejscem wydania były Bielsko i Biała, 1:1929 - 8:1936;

- „Głos Stanu Średniego", tygodnik bezpartyjny, kulturalno-polityczno-społeczny, miejscem wydania były Bielsko i Cieszyn, 1:1930 - 5:1935;

- "Hasło Polki”, miesięcznik dla kobiet, miejscem wydania było Bielsko, $1: 1934$ - 4:1938;

- „Młody Narodowiec", miesięcznik, miejscem wydania były Bielsko i Biała, 1:1929-9:1338;

- „Nasza Gazeta”, miesięcrnik młodzieży Państwowego Gimnazjum Polskiego w Bielsku, miejscem wydania było Bielsko, 1:1930 - 4/6:1935;

- „Placówka Kresowa”, tygodnik społeczno-narodowy, miejscem wydania było Bielsko, 1:1922 - 10:1931;

- „Przyszłość”, tygodnik, pismo Chrześcijańskiej Demokracji, miejscem wydania były Bielsko i Biała, 1:1920 - 12:1931;

${ }^{18}$ Relacja ustna: Karol Jaworski, Jaworze, 1986. 
- „Robociarz”, pismo ZZP przemysłu chemicznego w Polsce, Czechowice-Dziedzice-Bielsko-Żywiec-Goleszów, miejscem wydania były Czechowice, 1:1921 - 9:1929;

- "Wieniec - Pszczółka”, codzienne pismo dla ludu, miejscem wydania były Bielsko-Lwów-Cieszyn-Warszawa, 1:1875 - 59:1933 (w latach 1891-1898 Bielsko i Cieszyn);

- „Zjednoczenie”, tygodnik Narodowo-Chrześcijańskiego Zjednoczenia Pracy na Polskim Sląsku Cieszyńskim, miejscem wydania było Bielsko, $1: 1928-12: 1939$.

Oprócz prasy wydawanej na terenie powiatu docierały tutaj również czasopisma wydawane w innych rejonach polski, a nawet poza jej granicami. Dużą poczytnością wśród miejscowych Polaków cieszyła się wydawana od 1848 roku w Cieszynie "Gwiazdka Cieszyńska”. Od 1923 roku w Katowicach rozpoczęto wydawać "Gość Niedzielny", który został bardzo dobrze przyjęty przez katolików na Śląsku. Z kolei wyznawcy Kościoła ewangelicko-augsburskiego rozprowadzali wśród swoich wiernych takie czasopisma wydawane w Cieszynie, jak: „Nowy Czas”, pismo polityczne i ewangelickokościelne, tygodnik o nakładzie 1800 egzemplarzy; „Poseł Ewangelicki”, pismo poświęcone sprawom ludu ewangelickiego, tygodnik o nakładzie 800 egzemplarzy; "Głosy Kościelne”, pismo poświęcone sprawom zborów i misji wewnętrznej, dwutygodnik o nakładzie 2000 egzemplarzy $^{19}$.

W omawianym temacie trzeba również podkreślić, że działalność wydawniczą czasopism prowadziły również poszczególne szkoły i kółka zainteresowań. Aby sprostać zainteresowaniom uczniów, do poszczególnych szkół sprowadzano czasopisma specjalistyczne. I tak np. Państwowe Gimnazjum Polskie w Bielsku sprowadzało pisma: „Lotnik", "Morze”, „Młody Żeglarz" „Orli Lot", „Ziemia"20.

\section{CZYTELNICTWO I JEGO ZNACZENIE}

Śląsk Cieszyński posiadał bogate tradycje czytelnicze. Tutaj wychodziło wiele czasopism, omówionych już wcześniej, które stanowią do dziś oparcie dla ludu, wlewają w serca ożywioną wiarę. Dzięki poruszanym w nich treściom zdobywają sobie miano dobrych czasopism.

Odzyskana przez Polskę niepodległość otworzyła przed ludnością nowe możliwości. Kolportaż polskich książek i czasopism nie jest już ograniczany przez ludność narodowości niemieckiej. Mieszkający na tej ziemi Polacy sa otwarci na dobrą książkę i dobre czasopisma, chętnie biorą je do ręki. Na przeciw tym potrzebom wychodzą istniejące i tworzące się polskie organizacje, szkoły i parafie. Zakłada się przy nich biblioteki i czytelnie.

${ }^{19}$ P. P rawdzic, Protestantyzm na Ślasku Cieszyńskim w świetle prawdy. Cieszyn 1928 , s. $4-5$.

${ }^{20}$ J. K u ś, Szkice z dziejów Kościelnych Bielska Białej. Kraków 1984, s. 190. 
Szczególną rolę w tym względzie mają do spełnienia biblioteki szkolne i znajdujące się w nich książki. One bowiem mają wpływ na kształtowanie wartości u młodego człowieka. Dlatego w poszczególnych szkołach oprócz tradycyjnego nauczania organizuje się pomoc bratnią, którą zostają otoczeni zarówno uczniowie słabsi jak i biedniejsi.

Założona przy szkole przemysłowej w Bielsku biblioteka była podzielona na dwa zbiory: dla nauczycieli i dla uczniów. W roku 1928 zbiór nauczycielski liczył 821 woluminów, a uczniowski 1318. Z książek tych chętnie korzystali zarówno nauczyciele jak i uczniowie. Oprócz tego sprowadzano do szkoły różnego rodzaju czasopismaa specjalistyczne. Istniejąca przy niej od 1922 roku pomoc bratnia również dysponowała swoją biblioteką. W roku szkolnym 1930/31 liczyła ona 2555 woluminów. Większość z tych książek była o tematyce technicznej, naukowej i beletrystycznej.

Do Państwowego Gimnazjum Polskiego założonego w 1919 roku w Skoczowie, a po kilku latach przeniesionego do Bielska uczęszczało około 800 uczniów, zarówno Polaków, Niemców jak i Żydów. W szkole tej istniały cztery biblioteki: nauczycielska licząca 829 woluminów, uczniowska z książkami w języku polskim licząca 827 woluminów, uczniowska z książkami w języku niemieckim licząca 290 woluminów oraz biblioteka podręczników szkolnych dla uczniów biednych licząca 1253 woluminy. W szkole tej funkcjonowała również biblioteka świetlicowa, z której korzystali przede wszystkim uczniowie dojeżdżający ${ }^{21}$.

Oprócz bogatych zbiorów książek, w poszczególnych szkołach biblioteki prenumerowały różnego rodzaju czasopisma w celu poszerzenia wiedzy u swoich uczniów. Powstające w szkołach kółka zainteresowań także zakładają swoje biblioteczki i prenumerują czasopisma. Coraz częściej zakładano również w szkołach tzw. biblioteczki klasowe. Z biegiem upływu lat okazało się iż zamiast usprawnić one czytelnictwo ich istnienie wprowadzało wiele zamieszania. I tak np. uczniowie Gimnazjum Polskiego w Bielsku na łamach własnego czasopisma „Nasza Gazetka” wypowiadali się krytycznie o istnieniu na terenie jednej szkoły tylu bibliotek ${ }^{22}$. Jednak dostęp do bibliotek szkolnych był ograniczony, dlatego istniejąca pustkę starał się zapełnić Kościół otwierając przy parafiach czytelnie i biblioteki. Działalność ta obejmuje wszystkie trzy wyznania działające na tym terenie. Celem ich było dotarcie do szerokich mas ludu. Księgozbiory te znajdowały się w Domach Katolickich lub zakrystiach.

Szczególną role miały do spełnienia także czasopisma, które były sprowadzane na parafie i rozprowadzane wśród wiernych. Powodem częstszego sięgania po nie była przede wszystkim niska ich cena, co nie było bez znaczenia dla miejscowej ludności, wśród której w okresie międzywojennym

${ }^{21}$ W. Ćwiertnia, Biblioteka publiczna w Bielsku w latach 1720-1939, „Rocznik Biblioteczny, 12:1968, s. 117-118.

${ }^{22}$ J. K u ś, Szkice..., s. 192. 
przeważała ludność biedna. O ich przydatności świadczył nakład, częstotliwość z jaką się ukazywały oraz grupy do których były skierowane. Największą poczytnością wśród miejscowej ludności katolickiej cieszyły się czasopisma wydawane poza granicami powiatu bielskiego. Były to "Gwiazdka Cieszyńska" i "Gość Niedzielny". Trzeba również zaznaczyć, że ze względu na niemożność kupienia czasopisma przez każdą rodzinę wędrowały one często $\mathrm{z}$ domu do domu.

Wśród ewangelików największą poczytnością cieszyły się: „Nowy Czas”, „Poseł Ewangelicki” oraz „Głos Niedzielny”, wydawane również poza granicami powiatu, jak również wydawany w Bielsku w języku niemieckim „Neue Evangelische Kirchesseitung"23.

Od 1931 roku aktywnie w wydawanie czasopism włączyła się miejscowa gmina żydowska wydając własny tygodnik „Tygodnik Żydowski”. Jego nakład i czas ukazywania się jest trudny do ustalenia, gdyż w czasie działań wojennych cały księgozbiór wraz z czasopismami został zniszczony.

W nurt pogłębiania czytelnictwa szczególnie wśród ludności wiejskiej w sposób aktywny włączała się młodzież należąca do Akcji Katolickiej. Ona to przy poszczególnych parafiach organizowała kiermasze dobrej książki. Jedną z najaktywniejszych grup na tym terenie była młodzież należąca do parafii Bronów, która w 1938 roku zdobyła pierwszą nagrodę za największą procentowo do liczby mieszkańców sprzedaż książek.

Tabela 3. Prenumerata prasy katolickiej w niektórych parafiach powiatu bielskiego.

\begin{tabular}{|l|c|c|c|c|c|c|c|c|c|}
\hline \multicolumn{1}{|c|}{ Parafia } & $\begin{array}{c}\text { Liczba } \\
\text { parafian }\end{array}$ & $\begin{array}{c}1930 \\
\text { abonament }\end{array}$ & $\%$ & $\begin{array}{c}\text { Liczba } \\
\text { parafian }\end{array}$ & $\begin{array}{c}1933 \\
\text { abonament }\end{array}$ & $\%$ & $\begin{array}{c}\text { Liczba } \\
\text { parafian }\end{array}$ & $\begin{array}{c}1936 \\
\text { abonament }\end{array}$ & $\%$ \\
\hline Bronów & 760 & 34 & 4,5 & 850 & 20 & 2,2 & 895 & 25 & 2,9 \\
\hline Dziedzice & 6813 & 120 & 2,8 & 7634 & 90 & 1,5 & 7634 & 80 & 1,4 \\
\hline Bielsko & 13000 & 225 & 1,7 & 18000 & 280 & 1,5 & 18000 & 390 & 2,2 \\
\hline Czechowice & 4290 & 316 & 4,6 & 5885 & 200 & 2,7 & 5885 & 117 & 1,5 \\
\hline Międzyrzecze & 1193 & 26 & 2,2 & 1191 & 20 & 1,7 & 1191 & 72 & 6,0 \\
\hline Ligota & 2100 & 27 & 1,3 & 1960 & 21 & 1,1 & 1960 & 23 & 1,1 \\
\hline Rudzica & 2501 & 16 & 0,6 & 2513 & 12 & 0,4 & 2619 & 13 & 0,4 \\
\hline Zabrzeg & 1909 & 32 & 1,7 & 1915 & 50 & 2,6 & 1806 & 26 & 1,6 \\
\hline Kamienica & 1900 & 31 & 1,6 & 1900 & 87 & 4,6 & 1600 & 16 & 1,0 \\
\hline
\end{tabular}

Powyższa tabela obrazuje czytelnictwo $w$ parafiach katolickich powiatu bielskiego. Bez problemu dostrzegamy, iż mimo sprzyjających warunków i aktywności wielu osób oraz organizacji miało ono tendencję spadkową. Wyjątek stanowi tutaj parafia w Międzyrzeczu, gdzie następuje widoczny jego rozwój. Najgorsza sytuacja miała miejsce w parafii Rudzica, gdzie zaledwie $0,4 \%$ parafian prenumerowało czasopisma religijne. Trudno stwierdzić jednoznacznie gdzie popełniono błąd i jakie były powody zaistniałej sytuacji.

${ }^{23}$ P. P r a w d z i c, Protestantyzm..., s. 5. 


\section{DZIALALNOŚĆ KULTURALNA}

Odzyskana przez Polskę niepodległość stworzyła nowe możliwości i szansę głębszego rozwoju życia kulturalnego. Głównym ośrodkiem życia kulturalnego powiatu bielskiego stało się Bielsko. Tutaj w 1918 roku został założony teatr miejski, w którym grało się sztuki wybitnych polskich pisarzy np. Wyspiańskiego, Zapolskiej, Przybyszewskiego, Fredry. Także tutaj z gościnnymi występami przybywały teatry z innych miast, głównie Krakowa i Warszawy.

Oprócz sceny zawodowej w samym Bielsku, jak i na poszczególnych wioskach powstawały sceny i zespoły amatorskie. Organizowano je przy szkołach i parafiach. Najczęściej na ich repertuar składały się jasełka z okazji Świąt Bożego Narodzenia, oraz przedstawienia Męki Pańskiej w okresie Wielkiego Postu. Niektóre $\mathrm{z}$ tych zespołów próbowały swoich sił wystawiając również sztuki trudniejsze. Tak np. w Dziedzicach miejscowy zespół teatralny pod przewodnictwem ks. proboszcza K. Franka wystawił sztukę „Damy i Huzary” Aleksandra Fredry.

Wyrazem aktywności mieszkańców tej ziemi było zakładanie w poszczególnych miejscowościach zespołów regionalnych, których celem stało się kultywowanie miejscowej tradycji. Przy szkołach zakładano m.in. orkiestry szkolne, powstawały kółka literackie i sportowe. Wielość zakładanych kółek wpływała pozytywnie na ich poziom.

Wyrazem aktywności kulturalnej jest organizowanie różnego rodzaju wystaw ukazujący dorobek poszczególnych szkół czy organizacji. W życiu kulturalnym Bielska i okolicy ważnym wydarzeniem było zorganizowanie w 1933 roku w ,Strzelnicy" powiatowej wystawy szkolnej.

$\mathrm{Za}$ cel jej organizatorzy postawili sobie ukazać rozwój szkolnictwa na tym terenie, oraz współpracę polskich i niemieckich nauczycieli.

Eksponowano na niej między innymi mapy plastyczne, pomoce naukowe, zbiory owadów i kwiatów. Wiele miejsca poświęcono także pracom ręcznym. Wystawiono tablice statystyczne przedstawiające rozwój szkolnictwa na tym terenie. W sali przedstawiającej dorobek nauczycieli na uwagę zasługiwały prace literackie $i$ utwory muzyczne. Wysoki poziom prezentowały malarstwo i fotografia ${ }^{24}$.

Czynnikiem sprzyjającym aktywności był fakt, iż ludność tego terenu była różnych wyznań i narodowości.

\section{ROL A DUCHOWIEŃSTWA W ŻYCIU REI IGIJNO-SPOE FCZNYMM WYZNAWCÓW}

Życie religijne w parafii, jego rozwój i postęp zależy w dużej mierze od postaw duszpasterzy. Oni bowiem mieli wpływ na postawy swoich wiernych, byli dla nich często wzorem i przykładem. To właśnie kapłani, ich stanowczość, troska o dobro ludu decydowały często o jego losie. Dlatego ważną

\footnotetext{
${ }^{24}$ K. M a tu s i a k, Szkolnictwo..., s. 42-43.
} 
sprawą jest to gdzie się urodzili, studiowali, gdzie przed przyjściem na tę ziemię pracowali.

Duchowieństwo pracujące na tym terenie było narodowości polskiej. Pochodziło ono z samego Sląska Cieszyńskiego, Górnego Śląska oraz z Małopolski ${ }^{25}$. Księża przychodzący na te tereny czuli się Polakami i byli lojalni wobec swych parafian. Przykładem jest tutaj postawa ks. Jana Kunza, który przed objęciem parafii w Bronowie, w podaniu napisanym po polsku zapewnia, że będzie pracował sumiennie dla dobra całej parafii ${ }^{20}$. Odnośnie większych parafii trzeba podkreślić, że oprócz proboszcza w duszpasterstwo byli zaangażowani także księża wikarzy i księża katecheci. Studia swoje kandydaci do kapłaństwa odbywali w Ołomuńcu, Widnawie i Wrocławiu ${ }^{27}$.

Nieco inaczej przedstawiała się sytuacja jeśli chodzi o parafie ewangelicko-augsburskie. Wierni tych parafii $\mathrm{w}$ większości podawali się za Niemców i o takim nastawieniu otrzymywali swoich duszpasterzy. Podobnie jednak jak duchowieństwo katolickie, pochodzili oni najczęściej ze Śląska Cieszyńskiego. Studiowali na Uniwersytetach we Wiedniu, Jenie, Berlinie, Strasburgu, Warszawie czy Krakowie. Duszpasterze ci starali się, aby wierni powierzeni ich pieczy zawsze byli wierni swym proboszczom oraz przekonaniom ${ }^{28}$.

Oprócz katolików i protestantów w Bielsku była dobrze zorganizowana Gmina Żydowska. Na jej czele w okresie międzywojennym stał rabin Steiner opowiadający się po stronie narodowości niemieckiej. Warty podkreślenia jest jednak fakt, iż był on nastawiony przychylnie do Polaków, co uzewnętrzniło się przez wprowadzenie do szkół żydowskich języka polskiego ${ }^{29}$.

Opieka duszpasterska na omawianym terenie nie należała do łatwych. Czynnikiem utrudniającym była wielość wyznań. Kapłani stojący na czele poszczególnych parafii starali się uchronić swoje „owce” przed wpływem innych wyznań. Opieką duszpasterską starano się otoczyć wszystkich wiernych, nawet tych, którzy na co dzień stali z dala od Kościoła. Czynnikiem utrudniającym tą pracę była również różnica w duszpasterstwie miejskim i wiejskim niezależnie od wyznań.

Utworzenie diecezji Śląskiej przyczyniło się do większej aktywności duchowieństwa, oraz do większego wglądu kurii w prace poszczególnych duszpasterzy. Parafie omawianego terenu obejmowały nieraz po kilka miejscowości i przysiółków. Zjawisko to nie sprzyjało rozwojowi duszpasterstwa, wprost przeciwnie utrudniało je. Biorąc pod uwagę taki stan rzeczy, duszpasterze mimo wszystko starali się prowadzić taką akcję, aby swym zasięgiem objąć jak największą ilość osób. Oprócz tradycyjnych zajęć duszpasterskich do których zaliczamy odprawianie Mszy świętych, udzielanie sakramentów,

${ }^{25}$ Schematyzm..., 1927, s. 22-27.

${ }^{26}$ Józef K r ę tos z, Dzieje..., s. 58.

${ }^{27} \mathrm{~S}$. B y rd a, Dziesięcioleıni plan duszpasterski dla parafii św. Józefa w Zabrzegu, Tychy 1911, (maszynopis w posiadaniu autora), s. 24-25.

${ }^{28} \mathrm{~K}$. J a n i k, Z problemów reformacji, Warszawa 1981-82, s. 118.

${ }^{29}$ K. M a t u s i a k, Szkolnictwo..., s. 24. 
głoszenie kazań, naukę religii w szkole, organizowanie rekolekcji i misji, było organizowanie adoracji Najświętszego Sakramentu, nabożeństw okresowych oraz zakładanie i prowadzenie różnych organizacji Kościelnych. Celem tych organizacji było zarówno pogłębianie własnej wiary, jak również pomoc duszpasterzom $\mathrm{w}$ ich pracy przez docieranie do osób biednych, chorych czy samotnych. Organizacje te pomagały również w prowadzeniu na swoim terenie sierocińców, domów starców czy azylów dla ludzi ubogich ${ }^{30}$. Ważnym elementem życia każdej parafii były odpusty na które zapraszano znanych kaznodziei. Na te uroczystości przybywały liczne procesje z sąsiednich parafii na czele ze swymi duszpasterzami.

Szczególnym rodzajem duszpasterstwa była nauka religii w szkołach. Praca ta nie należała do łatwych ze względu na to, że w szkołach dochodziło do konfliktów. Uczący tam księża musieli często je rozwiązywać i łagodzić.

Jednym z przejawów żywotności Kościoła są różnego rodzaju organizacje i bractwa religijne. Na czoło wszystkich organizacji katolickich działających na tym terenie wysuwa się Akcja Katolicka licząca 1745 członków działająca w czterech grupach, oraz Bractwo Różańcowe i Żywy Różaniec liczące 3262 członków. Oprócz tego działały również: III Zakon Św. Franciszka; Kongregacja Maryi Dziewicy, Krucjata, Apostolstwo Modlitwy, Bractwo Serca Jezusowego i kilka mniejszych ${ }^{31}$. Starano się organizować różnego rodzaju zjazdy i zloty organizacji religijnych jak również pielgrzymek między innymi do Skoczowa, do miejsca narodzenia św. Jana Sarkandra, Piekar czy Częstochowy. Pierwszy zlot i zjazd dla członków Akcji Katolickiej dla diecezji Śląskiej odbył się w 1934 roku w Jaworzu, w którym uczestniczyło 600 osób, a przemówienie wygłosił ks. biskup Teofil Bromboszcz ${ }^{32}$.

Opieką duszpasterską w Bielsku otoczono również wojsko. W tym celu po utworzeniu diecezji Śląskiej został powołany kapelan Wojska Polskiego dla oddziałów stacjonujących w Bielsku którym został ks. major Antoni Miodoński, następnie ks. major Bronisław Nowak, a po jego odejściu ks. kapitan Antoni Hodys. Do dyspozycji kapelana wojskowego został oddany kościół Świętej Trójcy. W 1934 roku został on konsekrowany przez biskupa polowego Wojska Polskiego ks. Józefa Gawlinę. W każdą niedzielę i święta odbywały się w nim specjalne nabożeństwa dla żołnierzy ${ }^{33}$.

Podobnie jak duszpasterze katoliccy, również księża Kościoła ewangelicko-augsburskiego starali się otoczyć jak najlepszą opieką swoich wiernych. Było to o tyle utrudnione, że na tym samym terenie istniały tylko cztery zbory protestanckie. Nabożeństwa odbywały się zarówno w języku polskim jak i niemieckim. Podohnie jak księża katoliccy uczyli religii w szkołach, dbając o pogłębienie wiary u dzieci i młodzieży. Organizowano także nabożeństwa okolicznościowe, np. w Bielsku w związku ze sprowadzeniem

${ }^{30}$ Schematyzm, 1930, s. 35-37.

${ }^{31}$ J. Kręt os z, Dzieje..., s. 98.

${ }^{32}$ Akcja Katolicka na Ślasku, Katowice 1986, s. 12.

${ }^{33}$ Schematyzm, 1927, s. 22-23; 1936, s. 103-105; 1938, s. 38; Katalog Diecezji Katowickiej, 1986, s. 93-94. 
do kraju zwłok Juliusza Słowackiego czy odsłonięciem pomnika Narutowicza. Zakładano również różnego rodzaju organizacje. I tak w 1932 roku powstał Związek Polaków Ewangelików. Jako cel postawił sobie „Dbanie i kształtowanie życia polsko-ewangelickiego w środowisku bielskim i jego okolicy". W tym celu organizowano różne akademie, a młodzież biedną zaopatrywano w podręczniki. Kolejną organizacją był Związek Polskiej Młodzieży Ewangelickiej, założony również w 1932 roku. Organizował on w Bielsku i okolicy odczyty, przedstawienia, wieczernice, akademie. Obie organizacje posiadały własne chóry z którymi często wyjeżdżano na koncerty $^{34}$. Organizowano także zjazdy młodzieży. W roku 1932 zorganizowano drugi Zjazd Chórów. Troską duszpasterską otaczano również stacjonujących w Bielsku żołnierzy. Ich kapelanem był najpierw ks. pułkownik Grycz, a po jego odejściu ks. Buzek. Dla żołnierzy sprawowano również specjalne nabożeństwa w kaplicy na nowym cmentarzu. Co tydzień organizowano także dla żołnierzy godziny biblijne $e^{35}$.

Sytuacja gminy żydowskiej różniła się zdecydowanie od pozostałych dwóch wyznań. Największe ich skupisko znajdowało się w samym Bielsku, co zdecydowanie ułatwiało opiekę nad wiernymi. Tutaj posiadali własną synagoge, własny dom starców, szkoły i przedszkole. Swoją opieką otaczali również te pojedyncze rodziny, które mieszkały w poszczególnych wioskach. Oficjalne kontakty gminy żydowskiej z przedstawicielami innych wyznań ograniczały się tylko do spraw koniecznych ${ }^{36}$.

Nie można stwierdzić, aby na omawianym terenie były podejmowane jakieś wspólne akcje przez wszystkie trzy wyznania. Raczej każde z nich starało się pracować samodzielnie i stać się widoczniejszym od pozostałych.

Ważną pozycję w życiu religijnym odegrały również istniejące na tym terenie zakony. Domy ich znajdowały się w Bielsku i Dziedzicach. Były to: Siostry Służebniczki NMP, Ubogie Siostry Szkolne de Notre Dame, Siostry Felicjanki oraz Ojcowie Jezuici. Początki ich działalności na tym terenie sięgają przełomu XIX i XX w.

Towarzystwo Jezusowe przybywa do Dziedzic w 1906 roku z Krakowa. Zakładają dom rekolekcyjny i organizują w nim rekolekcje zamknięte, które sa głównym ich zadaniem. Są one organizowane zarówno dla świeckich jak i dla kapłanów. W miarę rozwoju ich domu i wzrostu liczby ojców oraz braci zaczynają się włączać w życie duszpasterskie. Oprócz działalności na miejscu, znajdujący się tam ojcowie prowadzą rekolekcje w okolicznych parafiach. Dom ten utrzymuje również kontakty $\mathrm{z}$ misjonarzami pracującymi w Afryce ${ }^{37}$.

Kolejnym zgromadzeniem działającym na tym terenie sa Siostry Felicjanki. Podobnie jak Ojcowie Jezuici przybyły do Dziedzic z Krakowa. Na początku swej działalności założyły sierociniec i ochronkę. W późniejszym

${ }^{34}$ Z problemów..., s. 128.

${ }^{35}$ Z problemów..., s. 129.

${ }^{36}$ K. M a t u s i a k, Szkolnictwo..., s. 22; relacja ustna: Helena Płachciok, Jaworze 1985.

${ }^{37}$ Schematyzm, 1927, s. 101-114; 1930, s. 150; 1931, s. 111. 
czasie prowadziły także hafciarnię i szwalnię. Liczba sióstr wahała się w granicach od 8 do $10^{38}$.

Drugim ośrodkiem działalności zakonów na tym terenie było miasto Bielsko. Tu 29 stycznia 1919 roku przybyły z Prowincji Panewnickiej Siostry Służebniczki NMP. Polem na którym rozwijały swą działalność byli opuszczeni chorzy. Każdego dnia obchodziły swych podopiecznych służąc im w ich codziennych potrzebach. Szczególny rozkwit ich działalności przypada na lata trzydzieste. Najpierw 1 maja 1934 roku otwieraja dom starców i kalek, a następnie w 1938 roku poradnię dla matki i dziecka oraz mleczną kuchnię, z której wydaje się posiłki bezdomnym. W szczytowym okresie ich działalności w domu tym pracowało około 15 sióstr $^{39}$.

$\mathrm{Na}$ terenie Bielska działały również Ubogie Siostry Szkolne de Notre Dame, które przybyły tutaj 31 października 1852 roku ze Lwowa. Działalność ich w Bielsku miała przede wszystkim charakter dydaktyczny i wychowawczy. Prowadziły bowiem szkołę ludową o polskim i niemieckim jezzyku nauczania, wydział seminarium nauczycielskiego, seminarium dla nauczania robót ręcznych, szkołę gospodarstwa domowego oraz internat i sierociniec. Liczba sióstr prowadzących tę działalność stale się zwiększała i w 1938 roku wynosiła 80 zakonnic $^{40}$.

Działalność tych zakonów wpisała się na stałe w krajobraz tej ziemi. Była potrzebna, a zarazem widoczna i przynosząca rezultaty. Ci wszyscy, którzy się z nią zetknęli dostrzegali ich pracę i bardzo ją cenili.

${ }^{38}$ Schematyzm, 1927, s. 110-118.

${ }^{39}$ Schematyzm, 1927, s. $112 ; 1936$, s. $257 ; 1938$, s. 137.

${ }^{40}$ Schematyzm, 1927, s. $114 ; 1938$, s. $14 ;$ J. M a t u s i a k, Szkolnictwo..., s. 28. 